\title{
Isolation and purification of viable Ureaplasma urealyticum cells free from medium components
}

\author{
SHULAMITH HoRowitz* and HAGIT GAL \\ Mycoplasma Laboratory, Department of Microbiology and Immunology, Faculty of Health Sciences, \\ Ben Gurion University of the Negev, Beer Sheva 84105, Israel
}

(Received 13 August 1990; revised 10 December 1990; accepted 8 January 1991)

\begin{abstract}
A procedure was devised to produce Ureaplasma urealyticum preparations free of adsorbed components of the growth medium, which contains high concentrations of serum. The ureaplasmas were cultivated in a medium containing PPLO-serum fraction as a replacement for horse serum. High titres of ureaplasmas $\left(>10^{7}\right.$ c.f.u. $\mathrm{ml}^{-1}$ ) were obtained. Harvested cells were then purified by Urografin density gradient centrifugation. By use of ${ }^{3} \mathbf{H}$ labelled ureaplasma cells and ${ }^{125}$ I-labelled medium components, a distinct band of viable cells devoid of serum constituents was demonstrated. The absence of medium components was verified by immunoblotting cells from this band with antiserum to medium components. Medium components that had been present before the purification procedure were undetectable in the purified cell fraction obtained. The viability of the purified ureaplasma cells represented an $85 \%$ recovery rate and their antigenicity, examined with anti-serotype specific antiserum, remained intact. This easy and reproducible procedure can be used to prepare purified ureaplasmas for investigation of ureaplasmal antigens and their expression and/or role in disease.
\end{abstract}

\section{Introduction}

The human mycoplasma Ureaplasma urealyticum inhabits the urogenital system of $40-80 \%$ of the sexually active population and is associated with numerous diseases in men, women and infants (non-gonococcal urethritis, pelvic inflammatory disease, chorioamnionitis, recurrent and spontaneous abortions, neonatal morbidity and mortality, and infertility) (Cassell et al., 1986, 1987; Taylor-Robinson, 1986; Hillier et al., 1988).

It has been suggested that only some of the 14 known serotypes of $U$. urealyticum may be pathogenic and that the others are not involved in disease (Robertson et al., 1986; Cassell et al., 1987; Naessens et al., 1988). To establish the pathogenic potential of individual serotypes requires identification of serotype-specific antigens. Such identification has been hindered by the high level of cross-reactivity noted among the serotypes.

In addition to true antigenic relatedness between serotypes (Robertson \& Stemke, 1982; Stemke \& Robertson, 1985; Horowitz et al., 1986; Razin et al., 1986; Thirkell et al., 1989), another reason for crossreactivity is the adsorption to ureaplasmal cells of medium components and especially constituents of serum present in high concentrations in ureaplasmal media. Such components adsorb to the surface of cultured strains which may subsequently be used both for preparation of reference antisera and as antigens in the detection assays. Therefore, the availability of purified ureaplasma cells, free of medium contaminants, should enhance the definition of ureaplasmal antigens, including those common to all serotypes and those that are serotype-specific, thus facilitating investigation of the role of these antigens in pathogenesis.

The aim of this study was to develop a procedure for the purification of ureaplasmal cells suitable for antigenic research and for the development of specific detection assays.

\section{Methods}

Strains. U. urealyticum reference serotypes were kindly donated by G. H. Cassell, Birmingham, Alabama, USA. Serotypes 1 to 8 were originally obtained from E. A. Freundt (Institute of Medical Microbiology, University of Aarhus, Aarhus, Denmark). Serotypes 9 to 14 were originally obtained from J. A. Robertson (Department of Medical Microbiology and Infectious Diseases, University of Alberta, Edmonton, Alberta, Canada).

Growth and harvesting. U. urealyticum cells (serotype 4) were cultured in Shepard's $10 \mathrm{~B}$ broth, but containing $5 \%(\mathrm{v} / \mathrm{v})$ agamma horse serum (Gibco) or $1 \%(\mathrm{v} / \mathrm{v})$ PPLO-serum fraction (Difco). Both types of $10 \mathrm{~B}$ media were supplemented according to Shepard (1983) with CVA enrichment $\left(5 \mathrm{ml} \mathrm{l}^{-1}\right)(\mathrm{Gibco})$ and glycyl-histidyl-lysine tripeptide 
$\left(20 \mu \mathrm{g}^{-1}\right)\left(\right.$ Sigma). Cultures were incubated at $37^{\circ} \mathrm{C}$ in an atmosphere of $5 \%(\mathrm{v} / \mathrm{v}) \mathrm{CO}_{2}$ to limit excessive $\mathrm{pH}$ increase. When the cultures reached $\mathrm{pH} 7 \cdot 2-7 \cdot 3$ cells were harvested by centrifugation (Sorvall RC5B centrifuge, rotor SS-34) at $27000 \mathrm{~g}$ for $40 \mathrm{~min}$ at $4^{\circ} \mathrm{C}$. After two washes with phosphate-buffered saline (PBS; $0.13 \mathrm{M}-\mathrm{NaCl}, 0.014 \mathrm{M}$ -

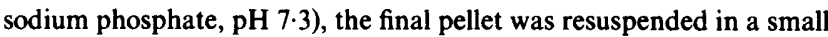
volume of PBS ( $1 \mathrm{ml}$ per litre of original culture). Non-inoculated broth controls were incubated identically and the $\mathrm{pH}$ adjusted to 7.2 before centrifugation.

Quantitative determination of organisms. The number of viable organisms in culture and during the isolation procedure was assessed by determining the number of colony-forming units (c.f.u.) $\mathrm{ml}^{-1}$ on $\mathrm{A} 8$ agar plates (Shepard, 1983). Growth curves of the ureaplasmas in broth were determined by monitoring both the increase in culture $\mathrm{pH}$ and the change in the number of c.f.u. during cultivation.

Radiolabelling: ${ }^{3} \mathrm{H}$-Labelled ureaplasmas were obtained by growing them in $10 \mathrm{~B}$ broth containing $\left[{ }^{3} \mathrm{H}\right]$ thymidine $\left[0 \cdot 1 \mu \mathrm{Ci} \mathrm{ml}^{-1}\right.$ $\left(3.7 \mathrm{kBq} \mathrm{ml}^{-1}\right)$; Nuclear Research Center, Negev, Israel]. ${ }^{125} \mathrm{I}-$ Labelled components of either horse serum or PPLO-serum fraction were prepared by the Iodogen method (Markwell \& Fox, 1978) (Amersham) and added to the culture medium to yield 2-3 $\times 10^{5}$ c.p.m. per $\mathrm{ml}$ of $10 \mathrm{~B}$ broth. The radioactivity of ${ }^{3} \mathrm{H}$-labelled cells was measured by a beta counter (Beckman), and that of ${ }^{125} \mathrm{I}$-labelled components by a gamma counter (Packard).

Isolation of ureaplasmas by density gradient. (I) Continuous density gradient. Labelled or unlabelled $U$. urealyticum cells $\left(10^{8}-10^{9}\right.$ c.f.u.) were resuspended in PBS containing $10 \mathrm{mM}-\mathrm{MgCl}_{2}$ and treated with DNAase I (2500 Kunitz Units $\mathrm{mg}^{-1}$; Sigma) to remove extracellular, labelled DNA fragments originating from dead cells. This was done at a concentration of $5 \mu \mathrm{g} \mathrm{DNAase} \mathrm{ml}^{-1}$ for $30 \mathrm{~min}$ at $37^{\circ} \mathrm{C}$. The cells were then washed once and layered onto a $20-60 \%(\mathrm{v} / \mathrm{v})$ continuous Urografin gradient (a mixture of meglumin diatrizoate and sodium diatrizoate, $76 \%$, v/v, for injection, Schering, Berlin, FRG). Following centrifugation at $85000 \mathrm{~g}$ (Beckman ultracentrifuge, rotor SW 28) for $2 \mathrm{~h}$ at $4{ }^{\circ} \mathrm{C}$, fractions of $1.0 \mathrm{ml}$ were collected from the top of the gradient downwards. All fractions were measured both for the presence of viable organisms (c.f.u.) and for the presence of labelled material (c.p.m.). The density of the fractions was estimated based on the distance of migration into the gradient.

(2) Discontinuous density gradient. This consisted of 20,32 and $40 \%$ (v/v) $(8.5 \mathrm{ml}$ each) and $60 \%(6 \mathrm{ml})$ Urografin layers. It was used as above.

Preparation of antigens for immunoblotting. Purified ureaplasmas collected from the density gradient were washed with PBS and centrifuged $(85000 \mathrm{~g}$ for $1 \mathrm{~h}$, Beckman SW 28 Rotor) to remove the Urografin. Washed pellets of cells obtained before and after purification by density gradient centrifugation were sonicated at $0{ }^{\circ} \mathrm{C}$ for $1 \mathrm{~min}$ at $80 \%$ power $(50 \%$ duty cycle; Heat-Systems Ultrasonic Inc) in the presence of the protease inhibitor PMSF $(0.01 \mathrm{mM})$. The sonicates were then treated with DNAase for $10 \mathrm{~min}$ at room temperature, followed by one wash, and resuspended in Laemmli sample buffer (Laemmli, 1970).

Antisera. Rabbit antiserum to serotype 4 was prepared and used as described previously (Horowitz et al., 1986). Rabbit antiserum to antigenic medium components was prepared by immunizing rabbits with $1 \mathrm{mg}$ of $10 \mathrm{~B}$ broth pellet per each injection, given intradermally. This antigen was emulsified in Freund's complete adjuvant for primary immunization and in incomplete Freund's adjuvant for the booster injections that were given at 2, 4 and 6 weeks, intradermally. Antibody levels were measured by enzyme-linked immunosorbent assay (ELISA), as previously described (Horowitz et al., 1986), but with slight modifications.
Immunoblotting. SDS-PAGE of ureaplasmal antigens was done according to the method of Laemmli (1970) using a 3\% (w/v, acrylamide) stacking gel and $10 \%$ resolving gel $(1 \mathrm{~mm}$ thick). Transfer to nitrocellulose and immunoblotting were done according to the procedure of Towbin et al. (1979). Rabbit antisera were diluted $1: 3200$, and horseradish-peroxidase-conjugated swine anti-rabbit IgG (DAKO-immunoglobulin, Denmark) was used at a dilution of $1: 1000$. Antigens were visually detected by colour reaction with 3,3-diaminobenzidine tetrahydrochloride dihydrate (Aldrich).

\section{Results}

\section{Cultivation of ureaplasma in serum-free medium}

Growth curves ( $\mathrm{pH}$ change and viability titres) of $U$. urealyticum serotype 4 cultured in 10B broth/horse serum and in 10B broth/PPLO-serum fraction were compared. As shown in Fig. 1, identical growth curves were obtained in both these culture media, with the same final yield of $10^{7}$ c.f.u. $\mathrm{ml}^{-1}$. Serotypes 3, 6, 7, 9 and 14 were also cultured in $10 \mathrm{~B}$ containing $1 \%$ PPLO-serum fraction and similar yields, in the range $8 \times 10^{6}-5 \times 10^{7}$ c.f.u. $\mathrm{ml}^{-1}$, were obtained for each of these serotypes. The somewhat lower titres $\left(3 \times 10^{7}\right.$ c.f.u. $\left.\mathrm{ml}^{-1}\right)$ obtained in the type of experiment depicted in Fig. 1 are probably due to interrupted incubation conditions resulting from the sampling procedure.

\section{Isolation of Ureaplasma cells on a density gradient}

U. urealyticum cells (serotype 4) were efficiently labelled upon cultivation in the presence of $\left[{ }^{3} \mathrm{H}\right]$ thymidine. A resuspended pellet of ${ }^{3} \mathrm{H}$-labelled cells $\left(3 \times 10^{6}\right.$ c.p.m. per $10^{9}$ c.f.u.) was subjected to isopycnic centrifugation as described in Methods. A separate band of labelled

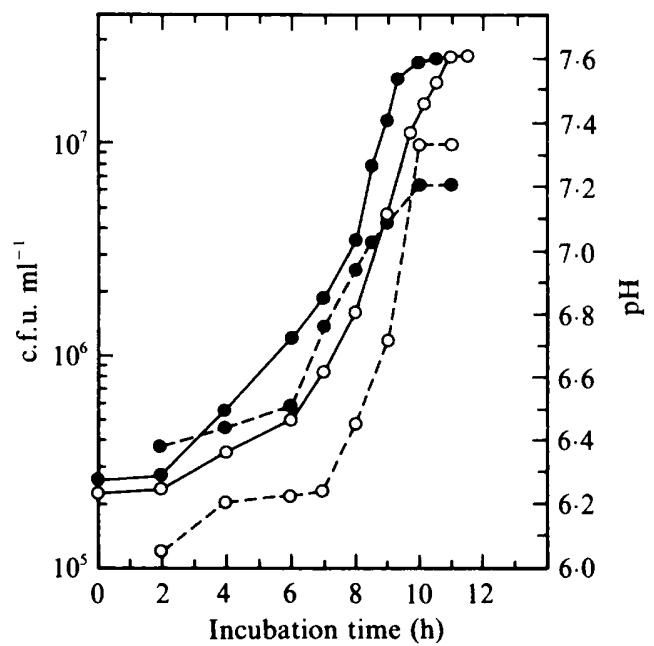

Fig. 1. Growth curves of $U$. urealyticum (serotype 4) in different media monitored by increase in culture $\mathrm{pH}(-)$ and by increase in c.f.u. $\mathrm{ml}^{-1}(---)$. Ureaplasmas were grown in $10 \mathrm{~B}$ broth $/ 5 \%$ horse serum $(\Theta)$ and in $10 \mathrm{~B}$ broth $/ 1 \%$ PPLO-serum fraction $(O)$. 


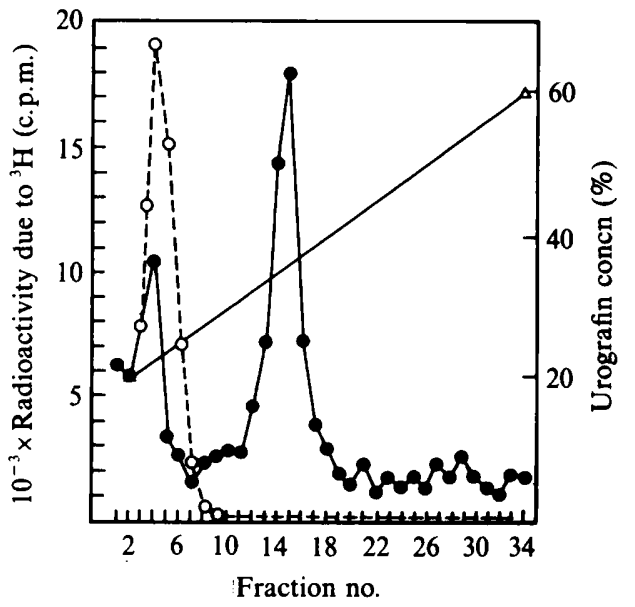

Fig. 2

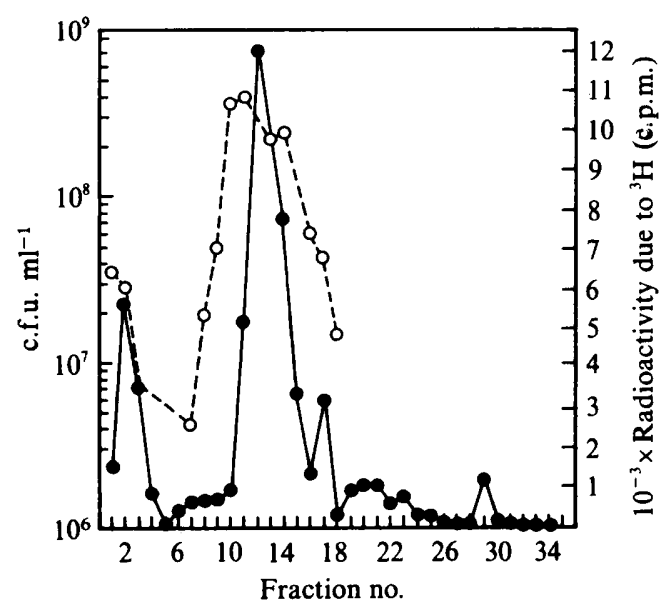

Fig. 3

Fig. 2. Isolation of ${ }^{3} \mathrm{H}$-labelled cells of $U$. urealyticum (serotype 4) on a $20-60 \%$ Urografin density gradient. The distribution of ${ }^{3} \mathrm{H}-$ labelled material obtained from a culture of ureaplasmas $(\Theta)$, is compared with that of an uninoculated medium control $(O)$. $\triangle$, Density gradient.

Fig. 3. Viability of $U$. urealyticum (serotype 4) cells separated on a Urografin density gradient. Viable cells were determined as the number of (c.f.u. $\mathrm{ml}^{-1} \mathrm{O}$ ); and ${ }^{3} \mathrm{H}$-labelled cells were determined by counting radioactivity (O). Note that the c.f.u. count is shown on a logarithmic scale while the radioactivity is on a linear scale.

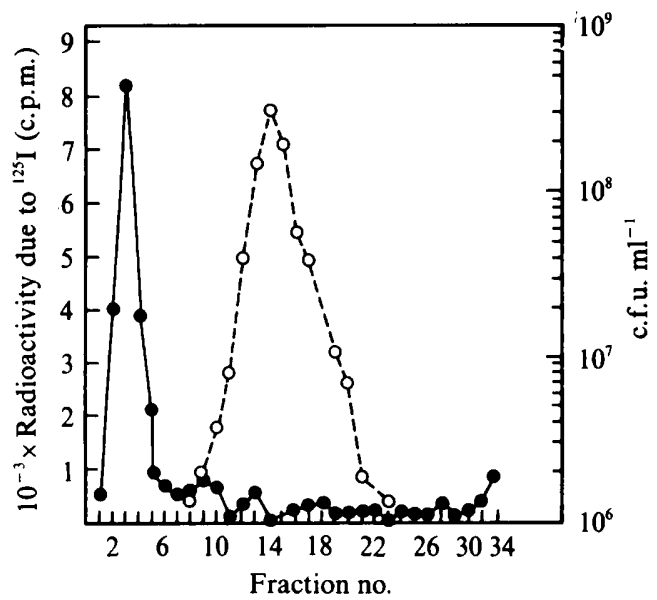

Fig. 4

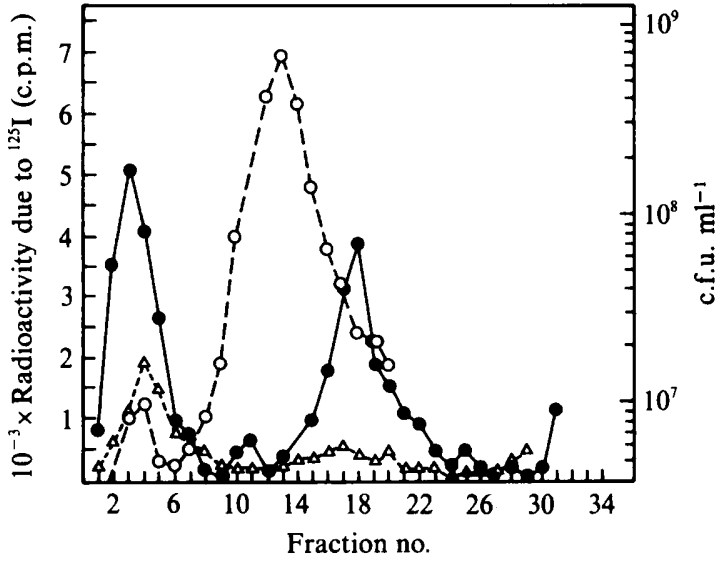

Fig. 5

Fig. 4. Isolation by density gradient centrifugation of purified cells of $U$. urealyticum (serotype 4) from a culture containing ${ }^{125} I$-labelled PPLO-serum fraction. The distribution of purified viable cells $(O)$ is compared with that of ${ }^{125} \mathrm{I}$-labelled medium components $(O)$.

Fig. 5. Isolation by density gradient centrifugation of purified cells of $U$. urealyticum (serotype 4) from a culture containing ${ }^{125}$ I-labelled horse serum. The distribution of viable cells (shown as c.f.u. $\mathrm{ml}^{-1} ; \mathrm{O}$ ) is compared to that of radioactivity in cells containing ${ }^{125} \mathrm{I}-$ labelled components $(\Theta)$ or an uninoculated labelled medium control $(\triangle)$.

cells was visible at $35-37 \%$ Urografin (fractions $13-16$ ) and it differed from the band obtained from the noninoculated labelled-medium control (fractions 3-6) (Fig. 2). The distinct fraction of labelled material at a density of $1 \cdot 23-1 \cdot 25 \mathrm{~g} \mathrm{~cm}^{-3}$ (35-37\% Urografin) coincided with the peak of viable cells and contained $80 \%$ of the total c.f.u. applied to the gradient (Fig. 3). In over 20 repeated experiments, the location of the cells in the gradient remained constant, and the yield of cells was $82-87 \%$.

\section{Removal of medium components from ureaplasma cells}

The separation of medium components from viable ureaplasmas by the density gradients was verified by analysing cells that were grown in 10B medium containing either ${ }^{125} \mathrm{I}$-labelled PPLO-serum fraction or ${ }^{125}$ I-labelled horse serum. As shown in Fig. 4, the distribution of the ${ }^{125} \mathrm{I}$-labelled PPLO-serum fraction components in the density gradient was distinct from 


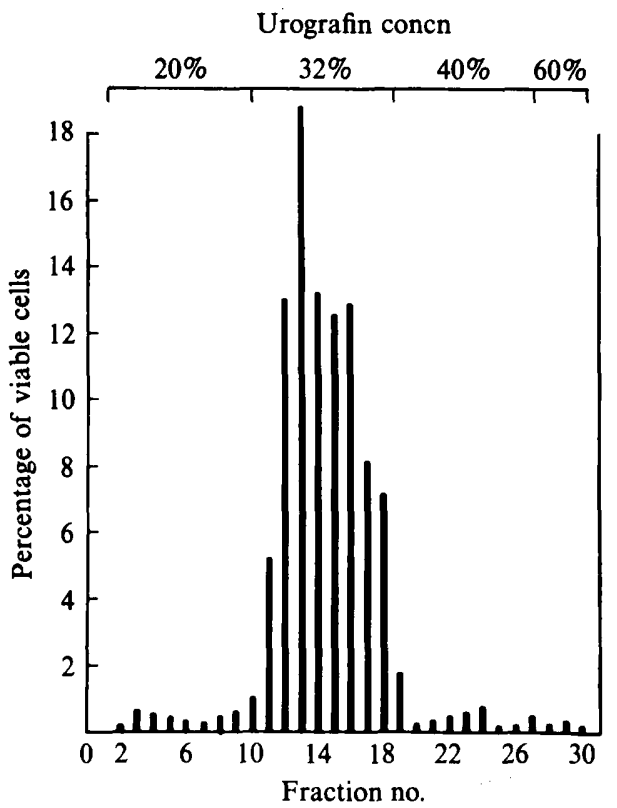

Fig. 6. Efficiency of the purification procedure. The percentage of viable $U$. urealyticum cells in the fractions obtained from a discontinuous Urografin density gradient is shown. The Urografin concentration in the gradient layers is indicated at the top of the Figure.

that of the ureaplasmas, and was located at $20-25 \%$ Urografin. Thus, the fractions containing viable ureaplasmas were devoid of ${ }^{125}$ I-labelled components, as shown by their location in a separate area on this gradient. Somewhat different results were obtained with cells grown in 10B containing ${ }^{125} \mathrm{I}$-labelled horse serum (Fig. 5). The ${ }^{125} \mathrm{I}$-labelled components exhibited two distinct peaks, the first at $20-25 \%$ Urografin (as in Fig. 4), while the second (at $38-43 \%$ Urografin), partially overlapped the viability peak. Thus, $85 \%$ of the viable cells separated in this band (= peak) (fractions 9-15) were not contaminated with ${ }^{125}$ I-labelled material. A sharp band of viable cells was also obtained by using a discontinuous gradient, which is very simple to prepare (Fig. 6). This band was obtained at the $32 / 40 \%$ Urografin interface, and the cells could be collected easily with high efficiency.

\section{Antigenicity of purified Ureaplasma cells}

The degree of purification of the ureaplasmas was further analysed by immunoblotting of cells before and after density gradient centrifugation. Equal amounts of ureaplasmas $\left(5 \times 10^{7}\right.$ c.f.u. $)$ from the suspension applied to the gradient and from the resuspended pellet obtained from the gradient, were compared. This was done by immunoblotting with antiserum to the medium components and with anti-ureaplasma antiserum. As demonstrated in Fig. 7, ureaplasmas before gradient centrifuga-

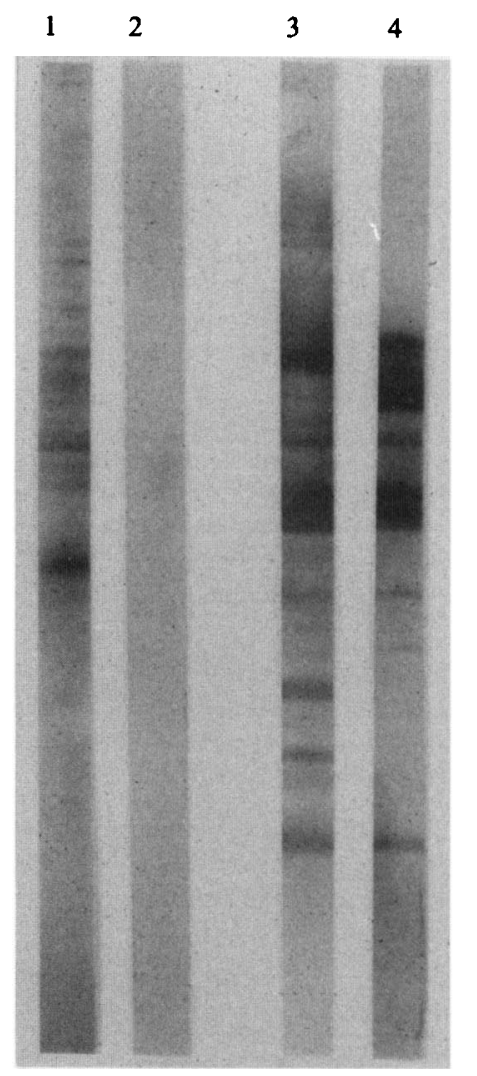

Fig. 7. Immunoblot of purified $U$. urealyticum (serotype 4) cells. Ureaplasmas before purification (lanes 1 and 3) and after purification (lanes 2 and 4) were reacted with rabbit antiserum to medium components (lanes 1 and 2) and with rabbit anti-serotype 4 antiserum (lanes 3 and 4).

tion contained multiple medium components, as detected by their reactivity with antiserum to the medium components (lane 1 ). In contrast, the gradientpurified cells did not contain these proteins (lane 2). In comparison, genuine $U$. urealyticum antigens remained unaffected (lanes 3 and 4), as seen by their reactivity with rabbit anti- $U$. ureaplasma (serotype 4 ) antibodies.

\section{Discussion}

We have shown that $U$. urealyticum can be cultured in medium in which PPLO-serum fraction is used to replace the horse serum commonly utilized for the cultivation of ureaplasmas. PPLO-serum fraction has been used previously to replace the serum components in culture media for other Mycoplasma and Acholeplasma species (Razin \& Rottem 1976; Rottem et al., 1977). The growth factors present in serum have been investigated (Rottem et al., 1971; Washburn et al., 1978; Johnson \& Somerson, 1980), but not fully defined. A modified medium, 
consisting of dialysate broth supplemented with whole serum, was previously used for antigenic analysis of Ureaplasma serotypes (Sayed \& Kenny, 1980), but it still contained horse serum components. PPLO-serum fraction is a much less complex supplement than whole horse serum and contains mainly lipoproteins and albumin (Smith et al., 1954; Washburn et al., 1978). Therefore, whereas ureaplasma cells grown in media containing horse serum adsorb many serum constituents, as do other mycoplasma cells (Bradbury \& Jordan 1972; Nicolet et al., 1980), cells grown in media containing PPLO-serum fraction would be expected to be devoid of such constitutents. We have also found that all 14 serotypes of $U$. urealyticum can be successfully cultured in the $10 \mathrm{~B}$ broth/PPLO-serum fraction, resulting in high yields of cells $\left(10^{7}\right.$ c.f.u. $\left.\mathrm{ml}^{-1}\right)$. These titres are comparable and in some cases higher than the yields obtained in $10 \mathrm{~B}$ broth/horse serum, as used in many laboratories. The reason for this better growth is unknown, but might be due to inhibitory factors which are known to affect certain batches of commercial sera used as supplements (Tully \& Rose, 1983).

Further purification of ureaplasma cells grown in the PPLO-serum fraction medium was achieved by density gradient centrifugation. Sodium metrizoate has been used successfully for density gradient separation in various systems for the purification of white blood cells (Lymphoprep), macromolecules, subcellular organelles and viruses (Kirshner et al., 1970; Grdina et al., 1973; Serwer,1975). A mixture of Metrizamide and sucrose was used for the separation of Mycoplasma hyorhinis from cultures (Wise et al., 1982) and Urografin, a mixture of meglumin diatrizoate and sodium metrizoate was used for the purification of Chlamydia trachomitis (Caldwell et al., 1981). However, we believe this to be the first report on the purification of viable Ureaplasma spp. by density gradient centrifugation. Purification of ureaplasmas on sucrose density gradients has been described previously (Rottem et al., 1971) but the organisms obtained were non-viable. Isolation of viable cells by sucrose density gradient centrifugation has been reported for $\mathrm{Myco}$ plasma fermentans (Williams, 1968), but not for Ureaplasma. Percoll gradient separation has been used for preparation of ureaplasmal antigens (Lee \& Kenny 1987), but details concerning the degree of purification, viability of cells and efficiency of the procedure were not reported. We have found that Urografin density gradients preserve viability more successfully than sucrose density gradients.

Final proof of the effective purification of ureaplasma cells was obtained by immunoblotting. Almost all of the medium components detected in a pellet of cells harvested from the medium were absent from the pellet of purified cells collected from the peak in the gradient.
In contrast, the reactivity of each ureaplasmal antigen with antiserum specific to that serotype was maintained throughout the purification procedures. The few ureaplasmal antigens that were undetectable after purification, when probed with rabbit anti-serotype 4 antiserum, could have represented antigenic medium components adsorbed to the cells used previously for immunization (Horowitz et al., 1986). The very weak protein bands seen in the immunoblots of purified cells reacted with anti-medium antibodies could be due to cross-reactivity between antigenic epitopes present both in medium components and in ureaplasma cells. Most of the ureaplasmal antigens remained unaffected by removal of the medium antigens.

Our results thus show that viable cells of $U$. urealyticum almost devoid of serum components can be isolated by means of Urografin density gradient centrifugation. This purification procedure is also applicable to ureaplasmas grown in traditional medium containing horse serum, albeit with a somewhat low efficiency.

The two major problems in isolating $U$. urealyticum and in identifying antigens and/or functions are, firstly, to obtain considerable numbers of cells, and secondly, to eliminate the medium components adsorbed to these cells. The procedure described in this paper makes it possible to obtain relatively large amounts of purified viable ureaplasma cells. These can be used to study functional aspects of intact cells (e.g. specific binding of purified ureaplasmas to host cell membrane, which otherwise may suffer from hindrance by serum components), and to determine their role in pathogenesis. This procedure will now enable us to investigate crossreactivity among the serotypes, without interference from cross-reactive non-relevant medium components. We intend to use these cells for the identification of surface antigens which might have been masked and/or altered by the contaminating constituents. These antigens will be further analysed for expression in disease and possible value in developing a specific detection assay.

This work was supported by grant no. 2722-186 from the Scientific Commission of the European Communities and the National Council of Research and Development, Israel. We are grateful to Professor S. Rottem for helpful discussions.

\section{References}

Bradbury, J. M. \& Jordan, F. T. W. (1972). Studies on the adsorption of certain medium proteins to Mycoplasma gallisepticum and their influence on agglutination and haemagglutination reactions. Journal of Hygiene 70, 267-278.

Caldwell, H. D., Kromhout, J. \& Schachter, J. (1981). Purification and partial characterization of the major outer membrane protein of Chlamydia trachomatis. Infection and Immunity 31, 1161-1176. 
Cassell, G. H., Clyde, W. A., Kenny, G. E., McCormack, W. M. \& TAYLOR-ROBINSON, D. (1986). Ureaplasmas of humans with emphasis upon maternal and neonatal infections. Pediatric Infectious Disease 5 (suppl.), S221-S354.

Cassell, G. H., Davis, J. K., Waites, K. B., Rudd, P. T., Talkinton, D., Crouse, D. \& Horowitz, S. A. (1987). Pathogenesis and significance of urogenital mycoplasmal infections. In Urogenital Infections, pp. 93-115. Edited by D. D. Stieritz, J. M. Campos \& L. A. Miller. New York: Plenum Press.

Grdina, D. J., Milas, L., HewitT, R. R. \& Withers, H. R. (1973). Buoyant density separation of human blood cells in renografin gradients. Experimental Cell Research 81, 250-254.

Hillier, S. L., Martins, J., Krohn, M., Kiviate, N., Holmes, K. K. \& EsCHENBACK, D. A. (1988). A case-control study of chorioamnionitic infection and histologic chorioamnionitis in prematurity. New England Journal of Medicine 319, 972-978.

Horowitz, S. A., Duffy, L., Garrett, B., Stephens, J., Davis, J. K. \& CASSEll, G. H. (1986). Can group and serovar-specific proteins be detected in Ureaplasma urealyticum? Pediatric Infectious Disease 5 (suppl.) S325-S331.

Johnson, J. K. \& Somerson, N. L. (1980). Cholesterol as a limiting factor in the growth of Mycoplasma pneumoniae. Applied and Environmental Microbiology 40, 391-399.

Kirshner, N., Wallach, D., Sharoni, Y. \& Schramm, M. (1973). Purification of secretory granules on a Urografin gradient. Analytical Biochemistry 52, 589-594.

LAEMmLI, U. K. (1970). Cleavage of structural proteins during the assembly of the head of bacteriophage T4. Nature, London 227 , 680-685.

LEE, G. Y. \& KENNY, G. E. (1987) Humoral response to Ureaplasma urealyticum polypeptides. Journal of Clinical Microbiology 25, $1841-1844$

MaRKwell, M. A. K. \& Fox, C. F. (1978). Surface-specific iodination of membrane proteins of viruses and eukaryotic cells using 1,3,4,6tetrachloro-3,6-diphenylglycoluvil. Biochemistry 17, 4807-4817.

Naessens, A., Foulon, W., Breynaert, J. \& Lauwers, S. (1988). Serotypes of Ureaplasma urealyticum isolated from normal pregnant women and patients with pregnancy complications. Journal of Microbiology 26, 319-322.

Nicolet, J., Paroz, Ph. \& Kristensen, B. (1980). Growth medium constituents contaminating mycoplasma preparations and their role in the study of membrane glycoproteins in porcine mycoplasmas. Journal of General Microbiology 119, 17-26.

RAZIN, S. \& RotTEM, S. (1976). Techniques for the manipulation of mycoplasma membrane. In Biochemical Analysis of Membranes, pp. 3-26. Edited by A. H. Maddy. London: Chapman and Hall.

RAZIN, S. \& Yogev, D. (1986). Genetic relatedness among Ureaplasma urealyticum serotypes (serovars). Pediatric Infectious Disease 5 (suppi.), S300-S304.

Robertson, J. A. \& Stemke, G. W. (1982). Expanded serotyping scheme for Ureaplasma urealyticum strains isolated from humans. Journal of Clinical Microbiology 15, 873-878.
Robertson, J. A., Honore, L. H. \& Stemke, G. W. (1986). Serotypes of Ureaplasma urealyticum in spontaneous abortion. Pediatric Infectious Disease 5 (suppl.), S270-S272.

Rottem, S., Pfendt, E. A. \& Hayflick, L. (1971). Sterol requirements of T-strain mycoplasmas. Journal of Bacteriology 105, 323-330.

RotTem, S., TROTTER, S. L. \& BARILle, M. F. (1977). Membrane bound thioesterase activity in mycoplasmas. Journal of Bacteriology 129, 707-713.

SAYED, I. A. \& KENNY, G. E. (1980) Comparison of the proteins and polypeptides of the eight serotypes of Ureaplasma urealyticum by isoelectric focusing and sodium dodecyl sulfate-polyacrylamide gel electrophoresis. International Journal of Systematic Bacteriology 30, 33-41.

SERWER, P. (1975). Buoyant density sedimentation of macromolecules in sodium iothalamate density gradients. Journal of Molecular Biology 92, 433-448.

SHEPARD, M. C. (1983). Culture media for ureaplasma. In Methods in Mycoplasmology, vol. 1, pp. 137-146. Edited by S. Razin \& J. G. Tully. New York: Academic Press.

Smith, P. F., LecCe, J. G. \& LynN, R. J. (1954). A lipoprotein as a growth factor for certain pleuropneumonia-like organisms. Journal of Bacteriology 68, 627-633.

STEMkE, G. W. \& Robertson, J. A. (1985). Problems associated with serotyping strains of Ureaplasma urealyticum. Diagnostic Microbiology and Infectious Diseases 3, 311-320.

TAYLOR-ROBINSON, D. (1986). Mycoplasma and mixed infections of the human male urogenital tract and their possible implications. In The Mycoplasmas, vol. 4, pp. 29-63. Edited by S. Razin \& M. Barile. New York: Academic Press.

Thirkell, D., Myles, A. D. \& Russell, W. C, (1909). Serotype 8- and serocluster-specific surface-expressed antigens of Ureaplasma urealyticum. Infection and Immunity 57, 1697-1701.

Towbin, H., Staehelin, T. \& GoRdon, J. (1979). Electrophoretic transfer of proteins from polyacrylamide gels to nitrocellose sheets: procedure and some applications. Proceedings of the National Academy of Sciences of the United States of America 76, 4350-4354.

Tully, J. G. \& Rose, D. L. (1983). Sterility and quality control of mycoplasma culture media. In Methods in Mycoplasmology, vol. 1, pp. 121-125. Edited by S. Razin \& J. G. Tully. New York: Academic Press.

Washburn, L. R., Hughes, J. H. \& Somerson, N. L. (1978). Mycoplasma growth factors in bovine serum fractions. Journal of Bacteriology 135, 818-827.

Wrlliams, M. H. (1968) In Recovery of Mycoplasma from Rheumatoid Synovial Fluid, Third Pfizer International Symposium on Rheumatic Diseases, pp. 171-181. Edited by J. J. R. Duthie \& W. R. M. Alexander. Edinburgh: University Press.

Wise, K. S., Minion, C. F. \& Cheung, H. C. (1982). Translocation of Thy- 1 antigen and a fluorescent lipid probe during lymphoblastoid cell interaction with Mycoplasma hyorhinis. Reviews of Infectious Diseases 4 (suppl.), S210-S218. 